\title{
Institutionalising a Withering Sense in Corporate Social Responsibility
}

\author{
Tan Seng Teck ${ }^{1}$, Selvamalar Ayadurai ${ }^{2}$, William Chua ${ }^{3}$, Tan Peng Liang ${ }^{1} \&$ Nanthakumar Karuppiah ${ }^{4}$ \\ ${ }^{1}$ Faculty of Business, Communication and Law (FOBCAL), INTI International University, Malaysia \\ ${ }^{2}$ Talenpac PLT, Malaysia \\ ${ }^{3}$ IPE School of Management, Pole Paris Alternance, France \\ ${ }^{4}$ University of Hertfordshire Centre, INTI International College, Malaysia \\ Correspondence: Tan Seng Teck, Faculty of Business, Communication and Law (FOBCAL), INTI International \\ University, Malaysia. E-mail: sengteck.tan@newinti.edu.my
}

Received: November 7, 2019 Accepted: December 13, 2019 Online Published: February 7, 2020

doi:10.5539/jms.v10n1p54 URL: https://doi.org/10.5539/jms.v10n1p54

\begin{abstract}
Studies and writings on corporate social responsibility turned a full cycle with much ink spilled on this topic. From the inception of a divine origin, corporate social responsibility has now become a flamboyant display of numbers and statistics which corporations proudly present them to fulfil their legal obligations. It is ironic that a divine understanding of corporate social responsibility has now transpired to be a complex calculus of statistical tabulations, too often exhibited in annual and sustainability reports. Organisations become grossly mesmerised with the grandiosity of exceeding the prerequisites of ecological, environmental, social and economic performance supported by undisputable, verifiable and measurable data. Corporate social responsibility has become senseless and meaningless. This is not a research paper nor does it entail the rudiments of any research findings. Conversely, this paper alerts and perhaps cautions corporate social responsibility practitioners on the perils of their overarching emphasis on positivism. Corporate social responsibility cannot be quantified merely in numbers but on the contrary, it should involve truthful, honest and transparent dialectic communication with the stakeholders. Many corporations deceived and some still facing the remnants of their mistakes. The Volkswagen 'diesel dupe' crisis and Johnson \& Johnson's baby talc powder scandals are reminders of the same. This paper is a solemn reminder that corporations must be 'awakened' so that ethics is grounded to its core and not merely in the cosmetic forms of presentable statistics.
\end{abstract}

Keywords: positivistic, corporate social responsibility, senseless, resisted, sensemaking

\section{Introduction}

The world has witnessed many major instances of unethical businesses. The 1984 Bhopal Disaster, the 1997 Nike Sweatshop Scandal, the Deepwater Horizon Oil spill in 2010, the Apple Foxconn scandal in 2017 and the most recent Johnson \& Johnson (J\&J) baby talc scandal in 2018 are some stark examples of unethical corporations. What do these corporations have in common? Other than the magnitude of social, environmental and economic impact, these scandals share one commonality. They are champions of corporate social responsibility (CSR) and displayed complex and highly institutionalised CSR reporting platforms. They annually table attractive data and statistics to reflect their CSR ingenuity. Despite their flamboyant claims, these organisations senselessly breached ethics to the core.

The emerging emphasis on institutionalised corporate reporting presents a lacuna in current CSR momentums. A firm's values are benchmarked on the accuracy and transparency of data they present their stakeholders. The advent of sustainability reporting instilled by the Global Reporting Initiatives (GRI) is an unembellished example. The GRI framework requires firms to categorically exemplify their sustainability performance through numerical presentation. Established in 1997, the GRI comprises of organisations and representatives from the Coalition for Environmentally Responsible Economic (CERES). Their mission was to develop a universally acceptable guideline for reporting on environmental, economic and social aspects. The stakeholder council in the GRI prescribes the layout and manner of reporting styles. A standard GRI report includes among others the key performance indicators (KPI) and a comprehensive report on the firm's social, environmental and economic performances. 
However, there are concerns that an institutionalised reporting approach inhibits truthful CSR, masks transparency (Ramdhony \& Hanuman, 2012), disguises corporate mischiefs (Sims, 1999) and pays premium to lip service (Maclean \& Rebernak, 2007). For example, Enron had in place very good CSR reporting mechanism boasting their corporate responsiveness and exceptional corporate citizenship (Sims \& Brinkmann, 2003). Similarly, in 2005, the Wall Street Journal applauded the apparel giant GAP Inc. for reporting the inspection of $99 \%$ of their vendors ensuring that their labour working conditions satisfied the required standards. However, Gap Inc. at that time was struggling to resolve discrimination and excessive workloads of their own workers (Lamin \& Zaheer, 2012). Another two colossal scandals involving Volkswagen's cheat device in 2015 and the currently ongoing criminal investigation on Johnson \& Johnson's cancer-causing baby talc allegations are stark reminders of a withering sense of CSR practices in modern business. This bags the question, what 'sense' does CSR entail when modern corporations are increasingly trespassing ethics at its core? Should CSR continue to transpire as a senseless corporate tool? This paper discusses the current trajectory of CSR reporting standards but more importantly impresses the point that the current direction leads to a withering sense in CSR. Perpetuating this trajectory is antithetical and counter intuitive to uncovering a sensible CSR. The authors schedule this paper as follows. Firstly, this paper summarises the CSR evolution, paying premium to the institutionalisation of CSR and their regulatory standards. Secondly, this paper elucidates why a senseless approach is inadequate in modern business world.

\section{Institutionalising CSR and its Withering Sense}

CSR was never institutionalised at its inception. On the contrary, many scholars argued that institutionalising CSR is philosophically antithetical. Tan et al. (2019) critically reviewed the CSR evolution by examining the extent of institutionalisation at every epoch of its evolution and his work projected that many classical scholars such as Bowen and Davis refuted this approach. Bowen (1953) for example maintained that social responsibility should remain as "the obligations of businessmen to pursue those policies, to make those decisions, or to follow those lines of action which are desirable in terms of the objectives and values of our society". The term corporate does not appear in Bowen's context. Clearly, the term social responsibility and CSR are relatively distinct. Bowen interpreted the word businessmen as the individual directors and executives of large corporations instead of the corporations themselves (Tan et al., 2019). Roland Benabou and Jean Tirole (2010) argued that there is striking distinction between social responsibility and CSR. They argued that social responsibility resembled a personal ethical execution, which is usually unstructured, ad hoc and unsystematic. CSR conversely is a corporately structured and collectively designed exercise. Bowen did not envisage an institutionalised and structured CSR commitment from corporations, but conversely appealed to the altruistic benevolence of the individual. In addition, Bowen maintained that social responsibility should remain voluntary and unregulated with government usurping a subliminal role. Conversely, other scholars in his time like Selekman (1958) and Kaysen (1957) advocate that corporations will remain as irresponsible oligarchs and will never voluntarily relinquish power in the absence of legal directives. Unlike Bowen, both authors support the institutionalisation of rules and regulations to enforce corporations' commitment on social responsibility.

Keith Davis like Bowen also resisted the government's interference and rejected regulating CSR. He argued that the central reason implementing social responsibility is to prevent regulatory intrusion. However, despite the lack of legal institutionalisation of CSR, Davis conversely argued that it is "socially mandatory" for corporations to fulfil social demands. Corporations must take responsibility for their powers failing which they will lose it (Davis \& Blomstrom, 1968). This is the 'iron law of responsibility'. Although Davis did not favour a regulatory regime, Davis surpasses Bowen's social responsibility voluntarism model by instilling a social institutionalisation of social responsibility. The iron law dictates a powerful social and or political sanction against defiant corporations, a more compelling factor for social responsibility compared to Bowen's charitable mode. Other scholars maintained almost similar notation. For instance, instead of instutionalising CSR, William Frederick (1978) rallied for a government-corporation partnership to tackle economic woes at industry and national levels. Lee and James (1981) argued that both corporations and nation states could benefit from drafting appropriate public policies that provided an aggregate guideline for firms. In their seminal work titled 'Private Management and Public Policy' published in 1975, they expressed that the public policies should reflect social demands which in turn guide the firms towards fulfilling those demands. This marks a marginal improvement in the attempt to at least formalise public policies to guide corporate behaviours. On a similar note, Carroll (1991) argued that the corporate philanthropic ideal is grounded on corporate volition. It is something that is highly prized but less important than other needs of firms fulfilling the economic, legal and ethical duties. Carroll labels philanthropic responsibilities as voluntary and an 'icing on the cake'. The notion of voluntarism demarcates an insignificant interest to institutionalise CSR.

One reason for the weak support of institutionalising CSR lies in the potency of the capitalist system. Capitalism 
presents the "triumph of the markets over individuals" (Bennett, 1999). Many writers exhort the notion of free enterprise and rejects institutionalising CSR. For instance, Milton Friedman's influential classical work titled 'The social responsibility of business is to increase its profit' published in 1970 argues that in a free enterprise, corporations are at liberty to maximise their profits as long as they abide within the law. Friedman asserts that the invocation of CSR constructs uninvited opportunities for governments to interfere in a free economy, one of the most illuminating hallmarks of laissez-faire. Many other CSR writers, including the more passionate ones like Bowen and Davis eschew from bluntly rejecting capitalism.

While earlier scholars shun institutonalising CSR, later writings favoured legitimation. For example, the emergence of corporate citizenship saw the sacrosanct of corporations to protect the fundamental civil, political and economic liberties of the society. Many corporations like Exxon Mobil, Nike and Ford incorporated the notion of citizenship in their corporate vision. However, unlike its predecessors, corporate citizenship achieved some extent of legal institutionalisation. For instance, the UN Global Compact (2002) stressed the ideality for corporations to forge cooperation with the civil society to instill citizenship. The UN Global Compact is the principal framework of global governance addressing ecological and social responsibilities of multinational companies (MNCs). Founded in the year 2000 by the late Kofi Annan during the 1999 World Economic Forum, the objective of the Compact was to foster a dialogue between corporations and the United Nation (UN) so that business firms could usurp a more systemic role in solving social woes guided by the ten principles (Voegtlin \& Pless, 2014). These principles ground the basis of annual reporting of those signatories. The reporting standards required among others to include a 'communication on progress' (COP) report. The report contained a structure including information on labour, anti-corruption, human rights and measurement of outcome (UN Global Compact, 2014b).

The currently entrenched concept of corporate sustainability presents yet another dynamic leap in institutionalising CSR. The novel motivation of corporate sustainability is ecological and environmental preservation (Montiel, 2014). Corporate sustainability is largely a scientific concern (Bansal \& Chan Song, 2017) which warned against deteriorating ecological environment. It inculcates an urgent call to remedy deploring environmental conditions. It fills the gaps of previous CSR seen to have underscored naturalist symbiosis (Montiel, 2014). The utmost contribution of corporate sustainability is the institutionalisation of mandatory sustainability reporting regulations. Following calamities like the Exxon Valdex catastrophe, social and global pressures instigated waves of legalisation that mandated sustainability reporting (Faisal et al., 2012; f). For instance, the U.S based Coalition for Environmentally Responsible Economies (CERES) launched the Global Reporting Initiative (GRI) with the objectives of establishing framework for reporting the "triple bottom line" paying emphasis to environmental performance. In Malaysia, Bursa Malaysia Berhad imposed obligatory disclosure for all publicly listed firms under Appendix 9C, Para 29 of the Bursa Malaysia Listing Requirements (Aman \& Takril, 2016).

The rise of standardised corporate reporting clearly signified the swelling grip of positivistic CSR. Positivism generally connotes any areas of study and research that hail an objectivist and a quantitative approach to a social inquiry. In a positivistic approach, social inquiries are deduced from measurable empirical data (Hammersley, 2018). Similarly, in business ethics, positivistic CSR quantifies the outcomes of CSR activities too often reported in sustainability reports, annual reports and corporate web pages. A positivistic CSR reporting method requires business firms to evident corporate citizenship and regulatory compliance (Carroll, 1998). Corporations must measure the outcomes of their CSR advocacies, quantified by predefined parameters and standards (Basu \& Palazzo, 2008). Positivistic CSR reporting is a form of content meta-analysis and connects CSR to corporate social performance (Orlitzky et al., 2003). The rising stakeholders' demands for more information and transparency propelled the escalating dominance of positivistic CSR approach. For example, external investment funds rely heavily on firms' activities benchmarked against their CSR performance (Basu \& Palazzo, 2008). There is currently an uprising dominance and upward trend of positivistic CSR practices fueled by those increasing quests for transparency and corporate updates. Global movements such as the GRI are powerful instigators propelling firms into a spiral of enigmatic sustainability reporting. Castello and Lozano (2011) argued that there is dominating pragmatic legitimacy in current reporting styles of many business firms with most attempting to gain legitimacy through semantic rhetoric. Indeed, research shows that the current sustainability reporting pattern is 'colonised' by overwhelming positivistic nuance paying premium to attaining pragmatic legitimacy (Castello \& Lozano, 2010).

However, there are two inherent difficulties of a positivistic approach in CSR reporting. Firstly, positivistic and content analysis approaches are perceived as simply recording and documenting CSR activities without appreciating their significance. A positivistic approach triggers homogeneous and standardised CSR reporting pattern (Sims \& Brinkmann, 2003). Furthermore, standardised CSR reporting often misleads the public with a 
façade of compliance. For instance, there are concerns that sustainability reporting frustrates the fundamental ethos of CSR (Safraty, 2013). A purely positivistic approach towards CSR triggers superficial and manipulative reporting (Aziz \& Bidin, 2017). This leads firms to apply a 'box ticking' approach towards compliance, which generates superficial and perhaps meaningless numerical postulations. A 'box ticking' approach triggers a "rigid, mechanical practice involving the use of needlessly detailed 'standardized checklists' and pursued without regard to weighing costs against benefits" (Safraty, 2013). In fact, there are concerns (Safraty, 2013) that overt emphasis on number churning encourages firms to emphasise on generating senseless but impressive numbers at the expense of doing good for public's interests.

This ultimately dilutes the primary purpose of sensemaking purposeful CSR. In this aspect, firms are senselessly engrossed in producing data and numbers to raise their status and showing compliance instead as a tool to aid organisation behavioural change. A study on Swedish firms by Hedberg and Malmborg (2003) evidenced that business firms such as Swedish Meats Inc. and Schenker adhered to GRI to gain recognition from external audits. Milne and Gray (2013) argued that superficial and cosmetic reporting requirements are "insufficient conditions to establish true CSR". Similarly, a mechanical box ticking approach engenders a "rigid, mechanical practice involving the use of needlessly detailed 'standardized checklists' and pursued without regard to weighing costs against benefits" (Safraty, 2013). The 2018 criminal investigation on J\&J pertaining to their allegedly cancer-causing baby talc is another resounding example of mishap in a positivistic CSR enigma. Surely, J\&J is renowned for their code of conducts. Their annual report reads "Complying with our Code is about creating an environment where we can do our best work and be proud of the work we do, the challenges we overcome and the successes we achieve all because we do these things fairly, legally and with integrity..." (J\&J Annual Report, 2017). Sethi and Schepers remarked in 2014 that:

A careful analysis of the UN Global Compact's activities to date leads these authors to conclude that UNGC is unlikely to be an effective vehicle of change in corporate social performance amongst its signatory companies in particular and private business organizations in general. UNGC's utter failure to demonstrate any progress - beyond counting increase in the number of signatory companies - is embedded in its operating 10 model is unlikely to change. This model is characterized by insular corporate governance, poor adherence to its own proclaimed standards, inadequate overall financing - and more notably from the corporate sector - its intended beneficiary" (Sethi \& Schepers, 2014)

Secondly, positivistic CSR emphasises pragmatic legitimacy where corporations manipulate CSR to gain competitive advantage. For instance, Nestle Inc.'s strategic cooperation with farmers in Moga India is an example of competitive advantage derived from CSR deployment (Porter \& Kramer, 2006). Others append CSR as part of a firm's triple bottom line (Elkington, 1998). The need to achieve environmental and social good coexists with the quest for profit. Body Shop Inc.'s effort in preserving the environment, protecting animals while generating profits is a precise example of the triple bottom line model (Body Shop, 2011). This approach lacks social sensemaking and CSR pitched on gaining collateral competitive advantage. This sort of fusion is insufficient to instill an ethical core in business firms and their CSR often camouflaged their ulterior business intent. While it is undeniable that these positivistic approaches have exponentially developed CSR, overt emphasis on positivistic contents inhibits firms from truly appreciating the intrinsic values of CSR (Brickson, 2007). This results in a vacuum for appreciating the underlying psychology, anthropological reasoning and sensemaking in CSR deployments. It leads to monotonous corporate reporting rendering it impossible to delineate any differences between various typologies of reporting patterns.

Furthermore, Palazzo and Scherer (2006) lamented that positivistic CSR momentums enrich a firm's egoistic self-interests. Pragmatic legitimacy embodies a capitalistic ideal that maximises both the corporate stakeholders' interests. In pragmatic legitimacy, firms do everything in their power to persuade their stakeholders to ascribe to their legitimacy through executing those CSR aimed at uplifting the interests of that group. The key driving factor in pragmatic legitimacy is to convince stakeholders that the corporation's leadership and their corporate strategies are collaterally beneficial to the firm and the society as a whole (Palazzo \& Shearer, 2006). Pragmatic legitimacy resembles a conscious cognitive sense where firms directionally and purposefully drive CSR initiatives to equalise their interests and the communities they serve. Belkaoui and Karpik (1989) argued that firms' disclosure of information is to gain social and political support. This aligns with an earlier study (Fry \& Hock, 1976) where the authors argued that firms gain political visibility through corporate disclosure. In their words "public relations gestures meant to ward off grass root attacks by social activists" (Fry \& Hock, 1976). In their concluding remarks, Belkaoui and Karpik (1989) and Blindheim and Langhelle (2010) argued that disclosures were necessary to gain pragmatic legitimacy. A recent study by Higgins et al. in 2018 also evidenced that pragmatic legitimacy directed firms to report in selective fashion and engaged only in those community or stakeholders that benefited their 
business. Clearly, a pragmatic legitimacy methodology creates businesses that are acutely aware of the strategic returns and advantages in selective alliance. Similarly, in Malaysia, research showed that business firms tightly control the amount and depth of information they disclosed. There are increasing discernment from stakeholders that they are not getting the fullest and most transparent of information, but instead attaining information that are carefully edited and their data doctored (Khan \& Ismail, 2014).

In addition, a positivistic CSR overtone diminishes a corporation's sense of moral legitimacy. Suchman (1995) defined moral legitimacy as "sociotropic"-it rests not on judgments about whether a given activity benefits the evaluator, but rather on judgments about whether the activity is "the right thing to do". These judgements resembled a barometer which benchmarks a firm's behaviours. Moral legitimacy relates to the subconscious moral mind of business firms. It reflects what the society deems as imperative, inevitable and non-negotiable moral values that firms must adhere (Palazzo \& Shearer 2006). In the words of Hannan and Carroll (1992) "there is little question in the minds of actors that it serves as a natural way to effect some kind of collective action". Any violation and or manipulation of this subconscious cognitive legitimacy risks firms defaced by intense social repugnance.

This paper argues that a positivistic corporate reporting approach instills a senseless CSR propulsion. This paper champions the view that the true values of CSR cannot be fully attained through a positivistic lens. An overt positivistic emphasis on CSR content is the leading cause for firms to omit understanding the contextual reasoning, anthropology and logic for their CSR implementations, the very core of a sensemaking process. This paper is not an empirical research. It does not churn attractive numbers and verify complex theoretical models. Far from it, this work cautions against heightened CSR institutionalisation and vents frustration on the intensifying senseless and meaningless CSR practices. This paper explores the reasons why a senseless positivistic and 'box ticking' model should be rejected and dismissed. A senseless CSR is paradoxical and enhances egoism. The following paragraphs explore some salient reasons why this must be resisted.

\section{Resisting a Senseless CSR and the Quest for Sensemaking}

This paper refutes and resists the advents of a positivistic and senseless CSR momentum. Primarily, organisations do not exist in vacuum but conversely, they are a social construct entrapped by the polarised interests of varied stakeholders. Modern corporations are regularly embroiled in ethical dilemmas, encounter social confrontations and negative externality (Kotler \& Caslione, 2009). Indeed, "There is recurring rift between big business and the rest of the society. They have never truly enjoyed a harmonious relationship with the society... There is urgency for businesses to reconnect with the society radically" (John Browne et al., 2016). This follows Keith Davis's comments in 1972 who forewarned that corporations are increasingly entangled in a pluralist society. Calamities like the Union Carbide Bhopal disaster, BP's 'Deep Water Horizon' and Exxon Valdez oil spill spawned visceral public outrage and reinvigorated the ideals of social responsibility (Bowen, 1953). Using a purely positivistic ideal in CSR reporting and gaining pragmatic legitimacy is inadequate.

Positivistic CSR presents a purposeful devise to interlink CSR and business (Donaldson, 1996) paying premium on how social accountability can be strategically included within a business framework. Positivistic CSR encouraged both managers and corporations to underlie their social values within their business decision (Hosmer \& Kiewitz, 2005) with emphasis placed in providing "a distinctive view of a corporation's overall efforts towards satisfying its obligations to society" (Wartick \& Cochran, 1985). The biggest concern is that positivistic CSR concepts overemphasised the ability of business entities to generate social change. There is overt presumption that moral disposition in organisations depends on the managers' ability to consciously steer the organisation to achieve better social outcomes. What a business organisation could do for the society is the primary question, one that fell short of explaining a cognitively ingrained sensemaking in business organisations. Positivistic CSR overlooked the importance on studying why and how a business organisation should react and respond towards externalities.

Positivistic CSR diminishes a firm's ability to sensemake CSR and achieve moral legitimacy. A firm that sensemakes CSR attains moral legitimacy, which in turn spawns reflexive organisation change and moral transpose. Positivistic CSR and pragmatic legitimacy can never capture such reflexive organisational developments. Tan et al. (2018) clearly explored this CSR sensemaking, reflexive organisation change and moral transpose in their work titled "A Theorisation on the Impact of Responsive Corporate Social Responsibility on the Moral Disposition, Change and Reputation of Business Organisations". Tan et al. (2018) explored the interface between CSR sensemaking, reflexive organisation change and moral transpose in the case of Shell's mismanagement of the Brent Oil Spar storage buoy saga in the Atlantic in 1995. The saga triggered backlash and public discontent resulting in Shell's share price decline and tattered reputation. The saga elicited Shell's 
'awakening' towards reflexive organisation change and moral realignment. One excerpt of Shell's annual report clearly epitomised this phenomenon.

We believe that we acted honorably in both cases. But that is not enough. Clearly, the conviction that you are doing things right is not the same as getting them right. For us at least, this has been a very salutary lesson. We were ready to learn from experiences, however painful, because of a planned process of change begun in 1994. It represented the most thorough and far reaching review for over 30 years-our Transformation. Nothing was sacrosanct, and fundamentals were questioned: the structure, the way business is done, the quality of leadership, relationships with people and our vision of the future (Shell Inc. Annual Report, 1998). [Emphasis added].

Shell appeared deconstructed by the saga that consecutively triggered sensemaking, reflexive organisational change and a moral transpose. Shell began sensemaking their crisis. Words and phrases such as "very salutary lesson" and "learn from experiences" are good examples of sensemaking. Words resembling "transformation" connotes reflexive organisation change and the fact Shell questioned their "fundamentals" reflects a moral transpose. Sensemaking provides a socially richer and ontologically denser CSR exploration. Sensemaking examines how business firms interpret and adapt to their externalities. Described as a process in which an individual or an organisation developed their cognitive connection with the environment (Ring \& Rands, 1989), sensemaking perceived CSR activities as not merely a positivistic measurable scheme, but how a business firm connects and adapts to their externality. Sensemaking constructs a unique social connection between the firm and its external environment and fulfilling their stakeholders' needs. This is consistent with the enactment model of organisational learning (Weick, 2001) which ascribed firms as constantly reflecting their evolving role in the business environment. Figure 1 below illustrates the lacuna between positivistic and sensemaking CSR.

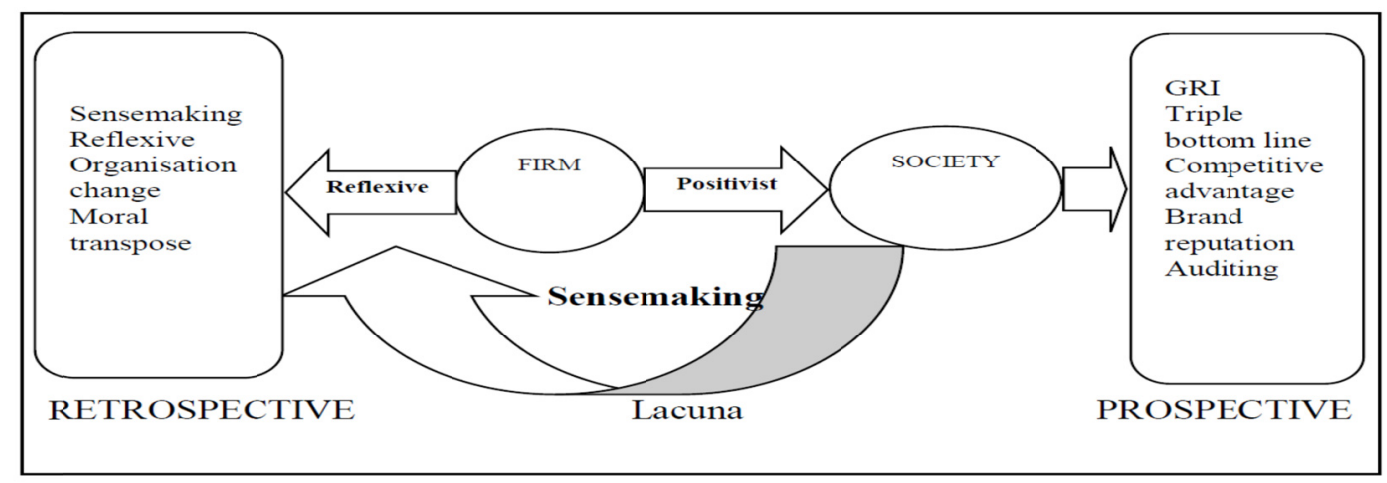

Figure 1. Lacuna between positivistic and sensemaking CSR

Source: Tan et al., 2019.

Figure 1 clearly illustrates the lacuna of this paper. Obviously, a positivistic CSR is prospective where firms assumed a proactive role in CSR deployment. A positivistic CSR deployment generates competitive advantage, triple bottom and enhances corporate repute. Conversely, sensemaking CSR connects the firm with the society. Firms reason their relationship with the society and retrospectively generate reflexive organisation change and moral transpose. Sensemaking involves a de-centering and deconstruction of the business organisation (Higgins, 2010). By this, it means that business firms no longer play a pivotal role to engineer social change, but instead they take a deconstructed role to sensemake and respond to stakeholders' demands. Unlike positivistic CSR, Sensemaking CSR have limitless ability to generate deeper and more meaningful organisational change and moral transformations in business firms rather than merely quantifying them. Sensemaking CSR scrutinises the organisation's deeper cognitive and conative values and not delimited by what they could do for the society.

Sensemaking departs from conventional positivistic content analysis but examines the intrinsic values of CSR and the outcome of the firms' interaction with their externalities. Instead of schematically measuring the outcomes of CSR, sensemaking sensibly decodes the psychological and cognitive responses of a business firm towards their externalities. It provides a more 'colourful' and multi-dimensional study of CSR. In the words of Basu and Palazo in 2008 "might provide a more robust conceptual basis, rather than simply analyzing the content of CSR actions within a certain context or over a certain period of time". Sensemaking analysis is robust because allows 
researchers and observers to fathom and comprehend the intrinsic intentions underlying a firm's CSR implementation. Furthermore, it allows researchers to scrutinise the changing dimensions of CSR implementations in a business firm and their moral implications. At a philosophical level, Sensemaking allows researchers to observe the moral transformations within a corporation at a deeper cognitive level. This point was well explored by Tan et al. (2018) who argued that firms could experience a moral transpose from utilitarianism to Kantianism. Using the context of Shell. Inc. Tan et al. (2018) argued that firms that encounter a crisis could experience a moral transition when they breach their cognitive legitimacy and face severe repulsions. Clearly, in the case of Shell. Inc. the firm has reset their moral values and ethical disposition, generated through a sensemaking approach and not possible through a positivistic context.

Secondly, as business firms are increasingly entangled in a fragile network of relationship with their stakeholders, it becomes necessary for organisations to make sense, change and adapt to those externalities. Organisational change has been a well-researched area and their literatures are abundant. However, modern business firms are increasingly experiencing sporadic, sudden and disruptive rather than planned organisation change (Scherer \& Palazzo, 2011). Conventional triadic and planned change models are inadequate to explain the more radical organisational change and moral dispose in business firms. Corporations embattled in crises, especially a moral crisis often triggers tsunamic changes within the firm. Such reflexive changes often morally reboot those firms, change their fundamental structures and culture (Maitlis \& Sonenshein, 2010). Again, the Shell Brent Oil Spar saga is a good evidence of such a deep change. A positivistic CSR and pragmatic legitimacy are inadequate to expose the impacts of a nonlinear and disruptive change (Tan et al., 2018). Instead, firms must embrace and fortify their cognitive legitimacy through constant sensemaking and maintaining a dialetic relationship with their stakeholders. Corporations are increasingly coerced to apologise and partake a more receptive posture when they err.

The recent Facebook data breach in 2018 is a relevant example of this punctuated change. At the congressional inquest, Mark Zuckerberg admitted that the firm has not done enough in protecting data security. Zuckerberg said, "it was a big mistake" and will "work through all changes" to repair it (Matthew Rosenberg et al., 2018). Post the saga, Facebook advertised in nine newspapers in United States of America (USA) and the United Kingdom (UK) and apologised their unethical deed. The headline reads, "I am really sorry that this happened... We have a basic responsibility to protect people's data, and if we can't do that, then we don't deserve the opportunity to serve people" (Al Jazeera Online News, 2018). Facebook experienced a deconstructive pressure, which resulted in the tumbling of $14 \%$ of its share value. Facebook had to reconsider its underlying moral values. Where pragmatic legitimacy supplies a skin-deep and senseless CSR analytic, cognitive legitimacy through sensemaking contributes to understand the deeper cognition and psychological implications when a firm experience moral transpose (Basu \& Palazzo, 2008). This method is aligned to the enactment and constructivist approach (Brickson, 2007) allowing researchers to contenxtualise the cognitive, conative and linguistic responses of their respondents during a radical organisation change.

Thirdly, sensemaking CSR helps to characterise organisation identity. Brickson (2007) theorised two types of organisation identity that are collectivistic and individualistic values that are deduced from the firms' fundamental assumption on their externalities. An individualistic organisation emphasises on self-interests, egoism founded upon an "atomised" perception that they are distinct and isolated from the externalities. Individualistic organisations often described themselves as "being the best" or "staying ahead of competition". In contrast, a collectivistic organisation displays a relational approach where they perceive themselves as integrated with the larger community as opposed to merely satisfying and fulfilling their duties to immediate stakeholders. Such collectivistic organisations portray a universal stand believing in CSR movements that are more generalised and abstract such as "we believe in saving the earth" or "we believe in eliminating hunger and poverty".

The implications of this diversion of organisation charaterisation is pivotal as they directly influence the pattern of relationship a firm chooses to stablish with their stakeholders (Brickson, 2007). These relationship structures conversely influence the pattern of CSR engagement within the business firms. Individualistic organisations would of course exhibit competition and strong strategic drive. On the other hand, a collectivistic organisation often de-contextualise their relationships and choose to address more abstract and universal issues regardless of their immediate relation to their core business values. They often engage in meta strategies tackling issues abstract issues such as global warming, environmental woes and sustainability.

Indeed, a constructivist approach to CSR contributes to contextualise CSR by sensemaking the rhetoric exposition in firm's annual and or sustainability reports. It helps researchers and stakeholders to identify implicit and discreet meanings and contextualise the linguistic, conative and cognitive postures of a business firm. It uncovers the hidden or concealed messages that firms do not consciously divulge. It enables reader(s) to seek 
deeper connection by scrutinising firms' responses, relegated through linguistic expressions. It enables reader(s) to identify the rhetoric reality gap and uncover the ulterior intents of business organisations. For example, positivistic CSR becomes a liability (Coombs \& Holladay, 2015) when disguised as greenwashing (Alves, 2009) or when applied in sinful industries (Ye et al., 2012). Consider the backlash of pragmatic legitimacy and positivistic CSR in Philip Morries youth anti-smoking campaign that backfired because detractors were sceptical of their actual intentions (Fairclough, 2001). Conversely, the contributions of sensemaking CSR on reputation salvage might produce better outcomes (Yeosun et al., 2006). A deconstructed firm develops cognitive reception with its external stimuli (Tan et al., 2018). It interprets, make sense and explores its extrinsic hostilities. Instead of pursuing a schematic and positivistic CSR momentum, these firms carefully sensemake their CSR by deploying an 'open' and receptive posture towards criticisms and setbacks (Basu \& Palazo, 2008). In contrast to a defensive disposition, an open posture indicates a firm's willingness to participate, listen and accept alternative perspectives. This is a powerful tool for crisis management. A tool Nike Inc. implemented to mitigate their child labour crisis. It was precisely reported by the Business Insider (2013) that:

... there's no denying that the company has executed one of the greatest image turnarounds in recent decades... By becoming a leader instead of denying every allegation, Nike has mostly managed to put the most difficult chapter in its history behind it and other companies who outsource could stand to learn a few things from Nike's turnaround [Emphasis added].

Fifthly, sensemaking CSR contributed to understand deeper the notion of organisational change. It is apparent that business firms experience deconstruction when they encounter external pressures. It is necessary for organisations to change so that they can adapt to the social shifts. Literatures on organisation change are plentiful, but organisation change involving sensemaking CSR and moral discourse is few. Earlier model presupposes a triadic mode of planned organisation change (Rosenbaum et al., 2018). Conventional planned models in organizational change postulate a gradual and predictable change in business organisations. Later organisation change models champion a more radical nonlinear approach. Gersick (1991) termed this as a punctuated equilibrium, which are capable of generating deep structural alterations and revolutions within the organization of change. This theorem is supported elsewhere (see Van De Ven \& Poole, 1995) where the study affirms that organisational change can consist of constructive patterns. Constructive change model explores the role of discontinuous change in the deconstruction of an organisation (see Higgins, 2010).

However, these studies shed little understanding on the stimulus of sensemaking CSR, the moral values underlying organisation change and particularly how organisational change in turn alters the discourse of relationship between the firm and its stakeholders. There is a need to fathom the intrinsic meaning behind these changing moral discourse instead of merely focusing on the change process. There is also a necessity to examine organisation change from an ethnographic perspective. Sensemaking CSR triggers a moral discourse in organisation change and business firms need to stretch their sociological and organisation imagination to capture the reflexive values rather than the change process itself (Mir et al., 2002). An anthropological approach to studying organisation change deserves attention (see Yanow 2014) so that there is adequate attention given on the reflexive ideals and making sense on the deeper values of organisation change (see Weick \& Sutcliffe, 2001). The works of Tan et al. (2017) studied this form of moral discourse and reflexivity. The examples of Shell's repentance from its Brent Oil Spar saga deeply construed an organsation change triggered by a swing in moral discourse, which transformed the business and its relationship with the society. Sensemaking CSR triggers organisational change that transcends regular structural change but one that is constructively fortified by a moral reboot and making sense on the deeper derivatives of change (Maitlis \& Sonenshein, 2010). There is paucity of literatures studying such moral reboot in organisation change. This lacuna deserves considerable attention because the inherent moral paradox in business practices attracts high possibility of a punctuated moral dispositioning. This sort of structural changes goes beyond window dressing, fortified by reformed moral values, and altered corporate conscience.

\section{Conclusion}

This paper is a stark reminder that corporations are not merely legal personalities. They are not isolated from the society nor are they above them. On the contrary, corporations are a subset of the wider community they serve. Corporations were established to solve social woes and profit is a collateral benefit that comes with it. However, the position is juxtaposed and there is growing assumption that corporations commands the society they once served. At the inception, corporate ethics is a naturally grounded business sense. Corporations must make profits fairly, supply goods and services that are worthy and refrain from fraud. Those were the grounded values in corporations, understood as being the core values of a business. Now, businesses have abandoned their core values and have instead perceived ethics as a source of competitive advantage. Corporations race and compete to 
produce the most articulate and well-tabulated CSR statistics. Some go at length to produce attractive graphs displaying those numbers of mathematical precision. These are meaningless when these numbers conceal the true intentions of a firm. Instead of being a tool for transparency, they were doctored and tailored to mask and façade the ugly deeds of a company. The Volkswagen diesel scandal is a painful reminder of this senseless CSR. This article serves a reminder and or caution to those CSR practitioners so that they will not be entrapped in this senseless rat race.

\section{References}

Acquier, A., Gond, J. P., \& Pasquero, J. (2011). Rediscovering Howard R. Bowen's legacy: The unachieved agenda and continuing relevance of social responsibilities of the businessman. Business \& Society, 50(4), 607-646. https://doi.org/10.1177/0007650311419251

Al Jazeera Online News. (2019). Retrieved November 1, 2019, from https://www.aljazeera.com/ajimpact/california-announces-probe-facebook-privacy-practices-191106202539 180.html

Alves, I. M. (2009). Green spin Everywhere: How Greenwashing Reveals the Limits of the CSR Paradigm. Journal of Global Change \& Governance, 2(1).

Aman, Z., \& Takril, N. (n.d.). Corporate Sustainability Reporting in Malaysia. Proceeding of the 3rd International Conference on Management \& Muamalah

Aziz, N. S. A., \& Bidin, R. H. (2017). A Review on the Indicators Disclosed in Sustainability Reporting of Public Listed Companies in Malaysia. Journal of Human Capital Development, 10(2), 1-14.

Ballou, B., Heitger, D., \& Landes, C. (2006). The rise of corporate sustainability reporting: A rapidly growing assurance opportunity. Journal of Accountancy, 202(6), 65-74.

Basu, K., \& Palazzo, G. (2008). Corporate social responsibility: A process model of sensemaking. Academy of Management Review, 33(1), 122-136. https://doi.org/10.5465/amr.2008.27745504

Belkaoui, A., \& Karpik, P. G. (1989). Determinants of the corporate decision to disclose social information. Accounting, Auditing \& Accountability Journal, 2(1). https://doi.org/10.1108/09513578910132240

Bénabou, R., \& Tirole, J. (2010). Individual and corporate social responsibility. Economica, 77(305), 1-19. https://doi.org/10.1111/j.1468-0335.2009.00843.x

Bennett, J. C. (1999). The End of Capitalism and the Triumph of the Market Economy. Network Commonwealth: The Future of Nations in the Internet Era.

Berger, P. L., \& Luckman, T. (1966). The Social Construction of Reality: A Treatise in the Sociology of Knowledge. Doubleday, Garden City, NY.

Blindheim, B. T., \& Langhelle, O. (2010). A reinterpretation of the principles of CSR: a pragmatic approach. Corporate Social Responsibility and Environmental Management, 17(2), 107-117. https://doi.org/10.1002/csr.235

Body Shop Inc. Annual Report. (2011). Retrieved December 6, 2019, from https://loreal-dam-front-corp-en-cdn.damdy.com/ressources/afile/2539-30db6-resource-1-oreal-2011-activit y-report.html

Bowen, H. R. (1953). Social Responsibilities of the Businessman. New York: Harper \& Row.

Brickson, S. L. (2007). Organizational identity orientation: The genesis of the role of the firm and distinct forms of social value. Academy of Management Review, 32(3), 864-888. https://doi.org/10.5465/amr.2007.25275679

Browne, J., Nuttall, R., \& Stadlen, T. (2016). Connect: How companies succeed by engaging radically with society. Random House.

Carroll, A. B. (1991). The pyramid of corporate social responsibility: Toward the moral management of $\begin{array}{llll}\text { organizational stakeholders. } & \text { Business } & \text { Horizons, } & \text { 34(4), }\end{array}$ https://doi.org/10.1016/0007-6813(91)90005-G

Carroll, A. B. (2008). A history of corporate social responsibility: Concepts and practices. In The Oxford Handbook of Corporate Social Responsibility (pp. 19-46). https://doi.org/10.1093/oxfordhb/9780199211593.003.0002

Castelló, I., \& Lozano, J. M. (2011). Searching for new forms of legitimacy through corporate responsibility 
rhetoric. Journal of Business Ethics, 100(1), 11-29. https://doi.org/10.1007/s10551-011-0770-8

Coombs, T., \& Holladay, S. (2015). CSR as crisis risk: expanding how we conceptualize the relationship. Corporate Communications: An International Journal, 20(2), 144-162. https://doi.org/10.1108/CCIJ-10-2013-0078

Davis, K., \& Blomstrom, R. L. (1968). Business and its environment. Academy of Management Journal, 11(2). https://doi.org/10.5465/amj.1968.4297423

Donaldson, T. (1996). Values in tension: Ethics away from home.

Elkington, J. (1998). Partnerships from cannibals with forks: The triple bottom line of 21 st - century business. Environmental Quality Management, 8(1), 37-51. https://doi.org/10.1002/tqem.3310080106

Fairclough, G. (2001). Philip Morris Notes Cigarettes' Benefits for Nation's Finances. Wall Street Journal, July, $16, \mathrm{~A} 2$.

Faisal, F., Tower, G., \& Rusmin, R. (2012). Legitimising corporate sustainability reporting throughout the world. Australasian Accounting, Business and Finance Journal, 6(2), 19-34.

Frederick, W. C. (1978). From CSR1 to CSR2: The maturing of business-and-society thought. Business \& Society, 33(2), 150-164. https://doi.org/10.1177/000765039403300202

Fry, F. L., \& Hock, R. J. (1976). Who claims corporate responsibility? The biggest and the worst. Business and Society Review, 18(18), 62-65.

Gersick, C. J. (1991). Revolutionary change theories: A multilevel exploration of the punctuated equilibrium paradigm. Academy of Management Review, 16(1), 10-36. https://doi.org/10.5465/amr.1991.4278988

Harrison, J. S., \& Wicks, A. C. (2013). Stakeholder theory, value, and firm performance. Business Ethics Quarterly, 23(1), 97-124. https://doi.org/10.5840/beq20132314

Hedberg, C. J., \& Von Malmborg, F. (2003). The global reporting initiative and corporate sustainability reporting in Swedish companies. Corporate Social Responsibility and Environmental Management, 10(3), 153-164. https://doi.org/10.1002/csr.38

Higgins, C. (2010). Is a responsive business also a responsible business. Journal of Business Systems, Governance and Ethics, 5(3), 23-32. https://doi.org/10.15209/jbsge.v5i3.186

Higgins, C., Stubbs, W., \& Milne, M. (2018). Is sustainability reporting becoming institutionalised? The role of an issues-based field. Journal of Business Ethics, 147(2), 309-326. https://doi.org/10.1007/s10551-015-2931-7

Hosmer, L. T., \& Kiewitz, C. (2005). Organizational justice: A behavioral science concept with critical implications for business ethics and stakeholder theory. Business Ethics Quarterly, 15(1), 67-91. https://doi.org/10.5840/beq20051513

Ioannou, I., \& Serafeim, G. (2017). The consequences of mandatory corporate sustainability reporting. In Harvard Business School research working paper (pp. 11-100).

Johnson \& Johnson Annual Report. (2017). Retrieved November 11, 2019, from http://www.investor.jnj.com/_document/2017-annual-report?id=00000162-2469-d298-ad7a-657fef1 c0000

Kaysen, C. (1957). The social significance of the modern corporation. The American Economic Review, 47(2), 311-319.

Khan, M. N. A. A., \& Ismail, N. A. (2012). Users' Perceptions of Various Aspects of Malaysian Internet Financial Reporting. Journal of Organizational Management Studies, 2012, 1. https://doi.org/10.5171/2012.852558

Kotler, P., \& Caslione, J. A. (2009). Chaotics: The business of managing and marketing in the age of turbulence. AMACOM Div American Mgmt Assn.

Lamin, A., \& Zaheer, S. (2012). Wall Street vs. Main Street: Firm strategies for defending legitimacy and their impact on different stakeholders. Organization Science, 23(1), 47-66. https://doi.org/10.1287/orsc.1100.0631

Lantos, G. P. (1999). Motivating moral corporate behavior. Journal of Consumer Marketing, 16(3), 222-233. https://doi.org/10.1108/07363769910271469

MacLean, R., \& Rebernak, K. (2007). Closing the credibility gap: The challenges of corporate responsibility 
reporting. Environmental Quality Management, 16(4), 1-6. https://doi.org/10.1002/tqem.20137

Maitlis, S., \& Sonenshein, S. (2010). Sensemaking in crisis and change: Inspiration and insights from Weick (1988). Journal of Management Studies, 47(3), 551-580. https://doi.org/10.1111/j.1467-6486.2010.00908.x

Milne, M. J., \& Gray, R. (2013). W(h)ither ecology? The triple bottom line, the global reporting initiative, and corporate sustainability reporting. Journal of Business Ethics, 118(1), 13-29. https://doi.org/10.1007/s10551-012-1543-8

Mir, A., Mir, R., \& Mosca, J. B. (2002). The new age employee: An exploration of changing employee-organization relations. Public Personnel Management, 31(2), 187-200. https://doi.org/10.1177/009102600203100205

Nisen, M. (2013). How Nike Solved Its Sweatshop Problem. Business Insider.

Orlitzky, M., Schmidt, F. L., \& Rynes, S. L. (2003). Corporate social and financial performance: A meta-analysis. Organization Studies, 24(3), 403-441. https://doi.org/10.1177/0170840603024003910

Palazzo, G., \& Scherer, A. G. (2006). Corporate legitimacy as deliberation: A communicative framework. Journal of Business Ethics, 66(1), 71-88. https://doi.org/10.1007/s10551-006-9044-2

Porter, M. E., \& Kramer, M. R. (2006). The link between competitive advantage and corporate social responsibility. Harvard Business Review, 84(12), 78-92.

Preston, L. E., \& Post, J. E. (1981). Private management and public policy. California Management Review, 23(3), 56-62. https://doi.org/10.2307/41172602

Ramdhony, D., \& Oogarah-Hanuman, V. (2012). Improving CSR reporting in Mauritius-accountants' perspectives. World Journal of Social Sciences, 2(4), 195-207.

Ring, P. S., \& Rands, G. P. (1989). Sensemaking, understanding, and committing: Emergent interpersonal transaction processes in the evolution of 3M's microgravity research program. In Research on the management of innovation: The Minnesota studies (pp. 337-366).

Rosenbaum, D., More, E., \& Steane, P. (2018). Planned organisational change management: Forward to the past? An exploratory literature review. Journal of Organizational Change Management, 31(2), 286-303. https://doi.org/10.1108/JOCM-06-2015-0089

Rosenberg, M., Confessore, N., \& Cadwalladr, C. (2018). How Trump consultants exploited the Facebook data of millions. The New York Times, 17(3), 2018.

Safraty, G. A. (2012). Regulating through numbers: A case study of corporate sustainability reporting. Va. J. Int'l L., 53, 575. https://doi.org/10.2139/ssrn.1915212

Sarpal, R., Teck, T. S., \& Fong, Y. S. (n.d.). A Critical Review on Porter's Integrated Approach towards Corporate Social Responsibility.

Scherer, A. G., \& Palazzo, G. (2011). The new political role of business in a globalized world: A review of a new perspective on CSR and its implications for the firm, governance, and democracy. Journal of Management Studies, 48(4), 899-931. https://doi.org/10.1111/j.1467-6486.2010.00950.x

Selekman, S. K., \& Selekman. B. M. (1956). Power and Morality in a Business Society. New York: McGraw-Hill.

Sethi, S. P., \& Schepers, D. H. (2014). United Nations global compact: The promise-performance gap. Journal of Business Ethics, 122(2), 193-208. https://doi.org/10.1007/s10551-013-1629-y

Sims, R. R., \& Brinkmann, J. (2003). Enron ethics (or: culture matters more than codes). Journal of Business Ethics, 45(3), 243-256. https://doi.org/10.1023/A:1024194519384

Suchman, M. C. (1995). Managing legitimacy: Strategic and institutional approaches. Academy of Management Review, 20(3), 571-610. https://doi.org/10.5465/amr.1995.9508080331

Tan, S. T., Ho, C. J., How, L. C., Karuppiah, N., \& Chua, W. (2018). A Theorisation on the Impact of Responsive Corporate Social Responsibility on the Moral Disposition, Change and Reputation of Business Organisations. J. Mgmt. \& Sustainability, 8, 105. https://doi.org/10.5539/jms.v8n4p105

The New York Times. (2008). Retrieved November 11, 2019, from https://www.nytimes.com/2019/10/04/the-weekly/johnson-johnson-baby-powder-cancer-lawsuits.html

Van de Ven, A. H., \& Poole, M. S. (1995). Explaining development and change in organizations. Academy of 
Management Review, 20(3), 510-540. https://doi.org/10.5465/amr.1995.9508080329

Van Maanen, J. (2006). Ethnography then and now. Qualitative Research in Organizations and Management: An International Journal, 1(1), 13-21. https://doi.org/10.1108/17465640610666615

Voegtlin, C., \& Pless, N. M. (2014). Global governance: CSR and the role of the UN Global Compact. Journal of Business Ethics, 122(2), 179-191. https://doi.org/10.1007/s10551-014-2214-8

Wartick, S. L., \& Cochran, P. L. (1985). The evolution of the corporate social performance model. Academy of Management Review, 10(4), 758-769. https://doi.org/10.5465/amr.1985.4279099

Weick, K. E., \& Sutcliffe, K. M. (2001). Managing the unexpected (Vol. 9). San Francisco: Jossey-Bass.

Yanow, D. (2014). Interpretive analysis and comparative research. In Comparative policy studies (pp. 131-159). Palgrave Macmillan, London. https://doi.org/10.1057/9781137314154_7

\section{Copyrights}

Copyright for this article is retained by the author, with first publication rights granted to the journal.

This is an open-access article distributed under the terms and conditions of the Creative Commons Attribution license (http://creativecommons.org/licenses/by/4.0/). 